Article

\title{
Sugar-Mediated Green Synthesis of Silver Selenide Semiconductor Nanocrystals under Ultrasound Irradiation
}

\author{
Daniela Armijo García ${ }^{1, *}$, Lupe Mendoza ${ }^{1}$, Karla Vizuete ${ }^{2}$, Alexis Debut ${ }^{2}{ }^{\mathbb{D}}$, \\ Marbel Torres Arias ${ }^{2}$, Alex Gavilanes ${ }^{2}$, Thibault Terencio ${ }^{3}{ }^{\circledR}$, Edward Ávila ${ }^{3}{ }^{(0)}$, \\ Clayton Jeffryes ${ }^{4(1)}$ and Si Amar Dahoumane ${ }^{1, *(1)}$
}

1 School of Biological Sciences and Engineering, Yachay Tech, San Miguel de Urcuquí 100650, Ecuador; lupe.mendoza@yachaytech.edu.ec

2 Center of Nanoscience and Nanotechnology, Universidad de las Fuerzas Armadas ESPE, Sangolquí 171103, Ecuador; ksvizuete@gmail.com (K.V.); apdebut@espe.edu.ec (A.D.); mmtorres@espe.edu.ec (M.T.A.); alexgavilanes1993@gmail.com (A.G.)

3 School of Chemical Sciences and Engineering, Yachay Tech, San Miguel de Urcuquí 100650, Ecuador; tthibault@yachaytech.edu.ec (T.T.); eavila@yachaytech.edu.ec (E.Á.)

4 Center for Advances in Water and Air Quality \& The Dan F. Smith Department of Chemical \& Biomolecular Engineering, Lamar University, Beaumont, TX 77710, USA; cjeffryes@lamar.edu

* Correspondence: cinthya.armijo@yachaytech.edu.ec (D.A.G.); sa.dahoumane@gmail.com (S.A.D.)

Academic Editor: Gregory Chatel

Received: 22 October 2020; Accepted: 5 November 2020; Published: 8 November 2020

\begin{abstract}
Silver selenide $\left(\mathrm{Ag}_{2} \mathrm{Se}\right)$ is a promising nanomaterial due to its outstanding optoelectronic properties and countless bio-applications. To the best of our knowledge, we report, for the first time, a simple and easy method for the ultrasound-assisted synthesis of $\mathrm{Ag}_{2} \mathrm{Se}$ nanoparticles (NPs) by mixing aqueous solutions of silver nitrate $\left(\mathrm{AgNO}_{3}\right)$ and selenous acid $\left(\mathrm{H}_{2} \mathrm{SeO}_{3}\right)$ that act as $\mathrm{Ag}$ and Se sources, respectively, in the presence of dissolved fructose and starch that act as reducing and stabilizing agents, respectively. The concentrations of mono- and polysaccharides were screened to determine their effect on the size, shape and colloidal stability of the as-synthesized $\mathrm{Ag}_{2} \mathrm{Se} \mathrm{NPs}$ which, in turn, impact the optical properties of these NPs. The morphology of the as-synthesized $\mathrm{Ag}_{2} \mathrm{Se}$ NPs was characterized by transmission electron microscopy (TEM) and both $\alpha$ - and $\beta$-phases of $\mathrm{Ag}_{2} \mathrm{Se}$ were determined by X-ray diffraction (XRD). The optical properties of $\mathrm{Ag}_{2} \mathrm{Se}$ were studied using UV-Vis spectroscopy and its elemental composition was determined non-destructively using scanning electron microscopy-energy-dispersive spectroscopy (SEM-EDS). The biological activity of the $\mathrm{Ag}_{2} \mathrm{Se}$ NPs was assessed using cytotoxic and bactericidal approaches. Our findings pave the way to the cost-effective, fast and scalable production of valuable $\mathrm{Ag}_{2} \mathrm{Se}$ NPs that may be utilized in numerous fields.
\end{abstract}

Keywords: green chemistry; silver selenide; nanoparticles; semiconductors; fructose; starch; in vitro toxicity; sonochemistry

\section{Introduction}

Semiconductor materials are technologically important due to their size-dependent optical, structural and electrical properties [1,2]. Phase-change chalcogenides have the ability to alternate between amorphous and crystalline phases with exposure to controlled energy inputs, making them an important material for a wide range of optical and electronic applications [3-6]. Silver selenide $\left(\mathrm{Ag}_{2} \mathrm{Se}\right)$, also known as naumannite, is a semiconductor material as a bulk and rarely found in nature as a mineral. It belongs to I-VI compounds with an optical band gap of 1.2-1.8 eV [7]. Among semiconductor 
nanomaterials, $\mathrm{Ag}_{2} \mathrm{Se}$ is one of the most widely investigated chalcogenide nanomaterials due to its countless applications, for instance, in electronics and the biomedical field [8,9]. Silver selenide is a mixed ionic conductor with a phase transition at atmospheric pressure from a low-temperature orthorhombic phase $\left(\beta-\mathrm{Ag}_{2} \mathrm{Se}\right)$, with a narrow direct band gap predicted by simulation to be $0.07-0.15 \mathrm{eV}$ at $0 \mathrm{~K}$, to a high-temperature cubic phase $\left(\alpha-\mathrm{Ag}_{2} \mathrm{Se},>407 \mathrm{~K}\right)[10]$. Orthorhombic $\beta-\mathrm{Ag}_{2} \mathrm{Se}$ is the most accepted crystal structure of $\mathrm{Ag}_{2} \mathrm{Se}$ due to its relatively high Seebeck coefficient (thermoelectric power, $-150 \mu \mathrm{V} \mathrm{K}^{-1}$ ) at $300 \mathrm{~K}$ and an unusually low lattice thermal conductivity coupled with high electrical conductivity [11]. $\beta-\mathrm{Ag}_{2}$ Se exhibits both photocatalytic activity and fluorescence. This compound has been used as a photosensitizer in photographic films, thermo-chromic materials for nonlinear optical devices and photovoltaic cells [12].

Conventionally, $\mathrm{Ag}_{2}$ Se nanoparticles (NPs) are produced by different methods, such as chemical conversion [13], hydrothermal reaction [14,15] and hot injection [16], while their microstructured analogs might be fabricated via, for instance, electrodeposition [17] and thermal evaporation [17]. However, these complicated and expensive methods involve both toxic chemicals and extreme conditions, generating hazardous toxic byproducts. As an alternative solution to this concern, "green chemistry" provides 12 principles as a guide in implementing less harmful synthesis methods [18].

Bioprocesses employing natural reagents, plant materials, microorganisms or their extracts have proven efficient in the synthesis of inorganic NPs, usually in a nontoxic, aqueous medium [19-21]. The green synthesis of NPs offers advantages over the traditional physical and chemical methods. In addition to working at mild temperatures, there is no need for high-pressure equipment. Moreover, the cost of disposing of solvents and chemical waste is significantly reduced. Overall, green synthesis is simple to carry out and cost-effective as it relies on renewable natural resources and results in more compatible and stable products [18].

Several routes have been devised in green nanotechnology, including biological methods [18], ultrasound (US) energy [22-24], microwave irradiation [25-28] or the use of Tollens' reagent [29,30] for the synthesis of valuable NPs of controlled shapes and sizes. However, nanoparticles are naturally unstable and tend to aggregate due to the onset of strong van der Waals forces [31]. Capping agents protect and passivate the particle surface preventing their agglomeration, as well as their uncontrolled growth [32]. Among the materials used as stabilizers, natural polymers and biomolecules, such as nucleic acids, lipids and proteins, provide an excellent steric hindrance effect along with potent stability [33-36].

Fructose, the monosaccharide used in this study, is a nontoxic reducing agent and constitutes a cheap and abundant natural source for the synthesis of inorganic NPs, such as AuNPs [37]. This reducing character is achieved in its open-chain form and maximized with its ionization [37]. In combination, reducing sugars and stabilizing biopolymers can mediate the formation of stable, morphologically controlled NPs.

Green approaches are also used to produce nontoxic and biocompatible nanoparticles for unique applications in industry [38] and biomedicine such as antibacterial, antifungal and antiviral agents [39-41]. Moreover, advances in modern medicine are driven by an increased use of NPs as efficient drug delivery vectors and powerful antimicrobial weapons [42,43]. Generally, inappropriate use and abuse of antibiotics are the main cause of induced antibiotic resistance in bacteria. Antibiotic-resistant bacterial infections may lead to high drug doses, higher toxicity treatments, prolonged hospitalization periods and an increase in morbidity and mortality [44].

In this context, the present article describes, for the first time, the sustainable production of silver selenide nanoparticles ( $\mathrm{Ag}_{2} \mathrm{Se} \mathrm{NPs}$ ) via a simple one-step ultrasound-assisted method by mixing aqueous solutions of silver nitrate $\left(\mathrm{AgNO}_{3}\right)$ and selenous acid $\left(\mathrm{H}_{2} \mathrm{SeO}_{3}\right)$ that act as $\mathrm{Ag}$ and Se sources, respectively. D-fructose is used as the reducing and coprecipitating agent for the formation of $\mathrm{Ag}_{2} \mathrm{Se}$ NPs, replacing toxic and harmful agents. On the other hand, starch acts as the stabilizing agent that controls the growth of $\mathrm{Ag}_{2} \mathrm{Se}$ NPs. Finally, the biological activity of these ecofriendly-synthesized $\mathrm{Ag}_{2} \mathrm{Se}$ NPs is assessed from cytotoxic and bactericidal points of view. 


\section{Results and Discussion}

\subsection{Visual Aspect of $\mathrm{Ag}_{2} \mathrm{Se} \mathrm{NPS}$}

The initial observation of the formation of $\mathrm{Ag}_{2} \mathrm{Se}$ NPs consists of a visual color change of the samples after ultrasound (US) irradiation. The results clearly show that the reaction mixture containing silver and selenium precursors, in addition to fructose and starch as the reducing and stabilizing agents, respectively, turns from white to brown after US irradiation (Figure 1A). The US irradiated control containing only $3.4 \mathrm{mM}\left[\mathrm{Ag}^{+}\right]_{\mathrm{f}}$ and $1.7 \mathrm{mM}\left[\mathrm{Se}^{4+}\right]_{\mathrm{f}}$ aqueous solutions showed no significant change in color (Figure 1B), confirming the effectiveness of fructose and starch as green agents when combined with US energy to promote the production of $\mathrm{Ag}_{2} \mathrm{Se}$ NPs.

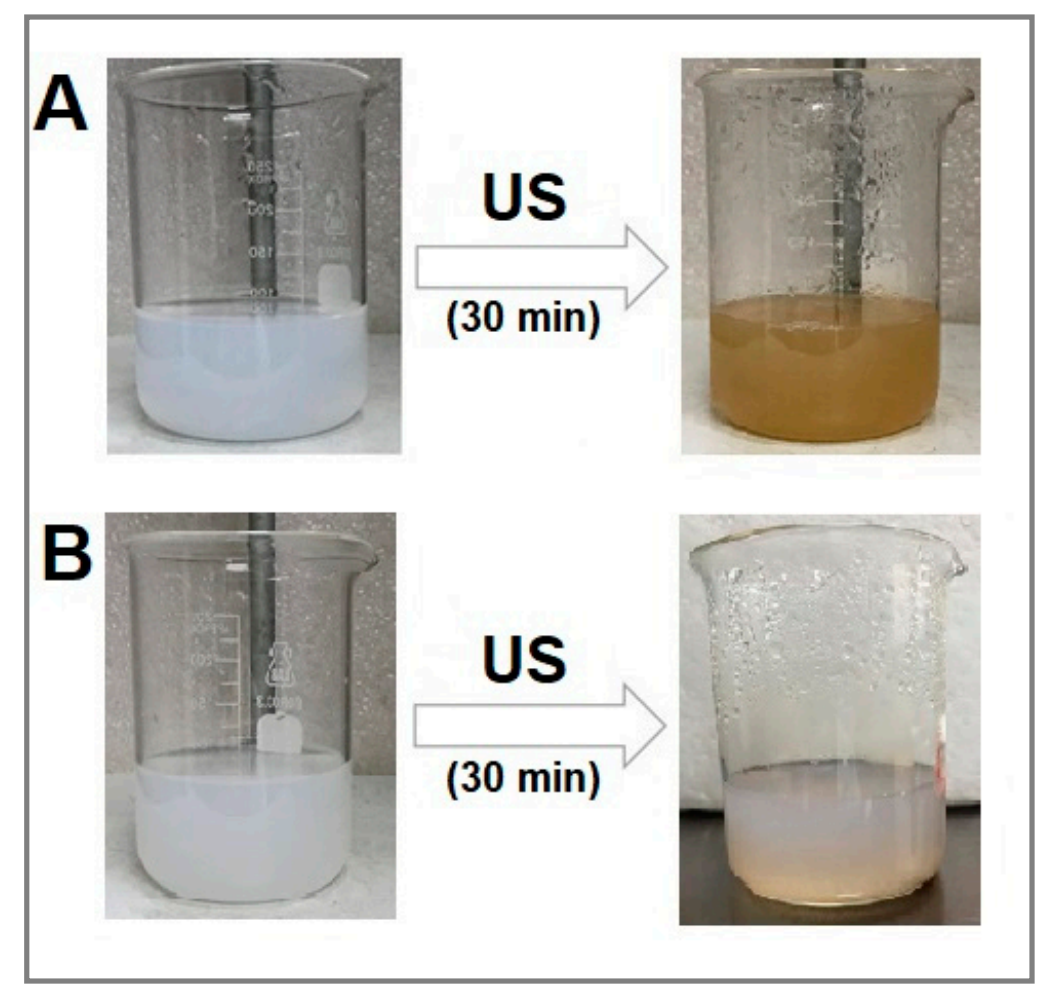

Figure 1. Pathway for the synthesis of silver selenide nanoparticles (NPs). (A) Sample made of $3.4 \mathrm{mM}$ $\left[\mathrm{Ag}^{+}\right]_{\mathrm{f}}$ and $1.7 \mathrm{mM}\left[\mathrm{Se}^{4+}\right]_{\mathrm{f}}$ in the presence of $40 \mathrm{mg} \mathrm{mL}^{-1}$ of fructose and $10 \mathrm{mg} \mathrm{mL}^{-1}$ of starch exposed to ultrasound (US) irradiation for $30 \mathrm{~min}$ (59-s pulse ON, 5-s pulse OFF). (B) Control sample made of $3.4 \mathrm{mM}\left[\mathrm{Ag}^{+}\right]_{\mathrm{f}}$ and $1.7 \mathrm{mM}\left[\mathrm{Se}^{4+}\right]_{\mathrm{f}}$ exposed to US irradiation under the same conditions as in (A).

\subsection{UV-Vis Spectroscopy}

The formation of $\mathrm{Ag}_{2}$ Se NPs was confirmed by the appearance of a unique and well-defined absorption band between 385 and $446 \mathrm{~nm}$ with a maximum at $413 \mathrm{~nm}$, similar to that reported in the literature $[45,46]$ (Figure 2A). In this range, the single absorption peak gives information about the shape, size and stability/aggregation of the NPs $[47,48]$.

It is notable that the intensity of the absorption band of the as-obtained $\mathrm{Ag}_{2} \mathrm{Se}$ NPs increases as the fructose concentration increases from 5 to $40 \mathrm{mg} \mathrm{mL}^{-1}$, while the other experimental parameters are kept constant (Figure 2A). This confirms the crucial role played by fructose in $\mathrm{Ag}_{2} \mathrm{Se}$ NP formation. Hypothetically, this process may consist of two steps: first, cationic selenium is reduced to $\mathrm{Se}^{2-}$ that, in turn, coprecipitates with cationic silver $\left(\mathrm{Ag}^{+}\right)$to subsequently give rise to $\mathrm{Ag}_{2} \mathrm{Se}$ NPs. The variations in the absorption intensities indicate significant differences in the particle number between the samples [49]. On the other hand, the corresponding UV-Vis absorption spectra of the 
control experiments $C_{1}, C_{2}$ and $C_{3}$ exhibit no absorption band (Figure 2B). This denotes either the absence of any $\mathrm{Ag}_{2} \mathrm{Se} \mathrm{NP}$ formation or the instability of any formed $\mathrm{Ag}_{2} \mathrm{Se}$ NPs.

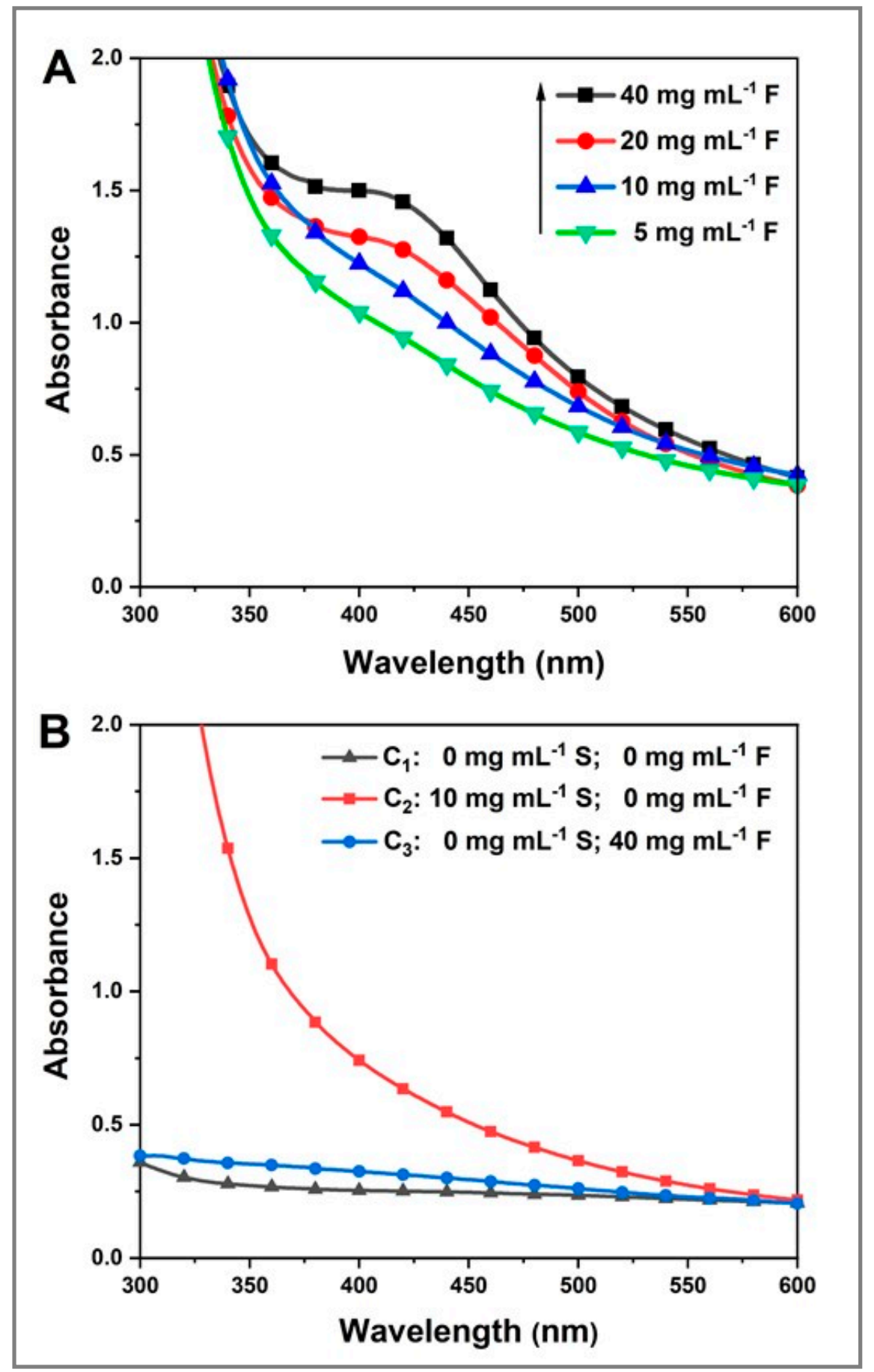

Figure 2. UV-Vis spectra of the as-synthesized $\mathrm{Ag}_{2} \mathrm{Se} \mathrm{NPs} ;(\mathbf{A})$ at different fructose concentrations and a constant starch concentration of $10 \mathrm{mg} \mathrm{mL}^{-1}$; and (B) control experiments. F: fructose; S: starch.

After confirming their production and the key role of fructose in this reaction, the colloidal stability of the $\mathrm{Ag}_{2} \mathrm{Se}$ NPs obtained from sample $\mathrm{E}_{4}$, made of $3.4 \mathrm{mM}\left[\mathrm{Ag}^{+}\right]_{\mathrm{f}}, 1.7 \mathrm{mM}\left[\mathrm{Se}^{4+}\right]_{\mathrm{f}}, 40 \mathrm{mg} \mathrm{mL} \mathrm{m}^{-1}$ fructose and $10 \mathrm{mg} \mathrm{mL}^{-1}$ starch and stored at room temperature (RT) in the dark, was monitored by recording its UV-Vis spectra at 15, 30 and 60 days (Figure 3). As a result, the absorption bands display similar features although a slight increase in the intensity after 30 and 60 days is noticed. 
This slight increase in the absorbance intensity might be attributed to either experimental errors or reorganization of the polysaccharidic matrix that surrounds and stabilizes the NPs. Furthermore, no signs of sedimentation were observed [50]. These findings confirm the stability of the as-produced $\mathrm{Ag}_{2} \mathrm{Se}$ NPs over a long period of time.

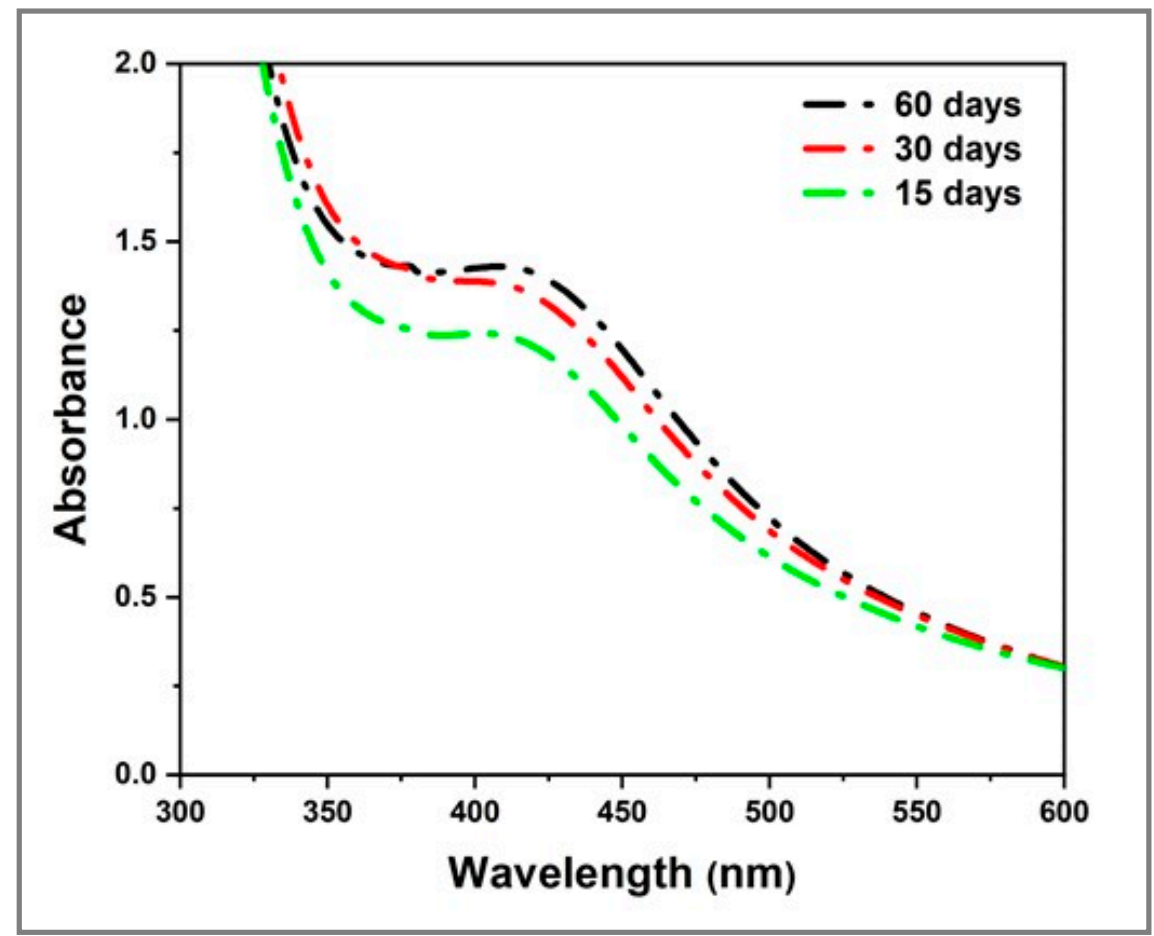

Figure 3. UV-Vis spectra of $\mathrm{Ag}_{2} \mathrm{Se}$ NPs obtained from sample $\mathrm{E}_{4}\left(3.4 \mathrm{mM}\left[\mathrm{Ag}^{+}\right]_{\mathrm{f}}, 1.7 \mathrm{mM}\left[\mathrm{Se}^{4+}\right]_{\mathrm{f}}\right.$, $40 \mathrm{mg} \mathrm{mL}^{-1}$ fructose and $10 \mathrm{mg} \mathrm{mL}^{-1}$ starch) stored at RT in the dark recorded at 15, 30 and 60 days.

Figure 4 displays the Tauc plots, i.e., $(\alpha h v)^{1 / n}$ vs. $(h v)^{2}$ of the $\mathrm{Ag}_{2}$ Se NPs obtained from samples $\mathrm{E}_{3}\left(3.4 \mathrm{mM}\left[\mathrm{Ag}^{+}\right]_{\mathrm{f}}, 1.7 \mathrm{mM}\left[\mathrm{Se}^{4+}\right]_{\mathrm{f}}, 20 \mathrm{mg} \mathrm{mL}^{-1}\right.$ fructose, $10 \mathrm{mg} \mathrm{mL}^{-1}$ starch $)$ and $\mathrm{E}_{4}\left(3.4 \mathrm{mM}\left[\mathrm{Ag}^{+}\right]_{\mathrm{f}}\right.$, $\left.1.7 \mathrm{mM}_{\left[\mathrm{Se}^{4+}\right.}\right]_{\mathrm{f}}, 40 \mathrm{mg} \mathrm{mL}^{-1}$ fructose, $10 \mathrm{mg} \mathrm{mL}^{-1}$ starch). The plots reveal that the $\mathrm{Ag}_{2} \mathrm{Se}$ NPs undergo both direct and indirect transitions. In this particular case, the direct transition (Figure 4A) seems to have two linear segments with a possible second band gap that could come from the two phases determined in XRD (vide infra) and/or may be due to the presence of a bimodal NP population as observed with TEM (vide infra). The occurrence of both direct and indirect transitions was also previously reported for $\mathrm{Ag}_{2} \mathrm{~S}$ NPs and $\mathrm{Ag}_{2} \mathrm{Se}$ NPs [51]. The indirect band gaps of samples $\mathrm{E}_{3}$ and $\mathrm{E}_{4}$, displayed in Figure 4B, were found to be 1.95 and $1.92 \mathrm{eV}$, respectively, which suggests optical absorption at wavelengths below 635 and $645 \mathrm{~nm}$, respectively. The direct band gaps of the same samples were found to be 2.41 and $2.45 \mathrm{eV}$, respectively (Figure $4 \mathrm{~A}$ ). In other words, there is no significant difference between these two band gap values, therefore the amount of fructose does not seem to have any impact on the band gap of the as-produced $\mathrm{Ag}_{2} \mathrm{Se}$ NPs. However, the band gap values of these $\mathrm{Ag}_{2} \mathrm{Se}$ NPs are higher than the ones experimentally estimated for thin films of the same material $(1.37 \mathrm{eV})$ [52] or for their bulk counterpart $(0.16 \mathrm{eV})$ [11], suggesting that it is possible to modify the band gap by tailoring the NP size. The difference between the reported values and the obtained $E_{g}$ can be attributed to the appearance of a series of discrete states in the conduction and valence bands yielding an $E_{g}$ increase in quantum size systems [53,54]. 


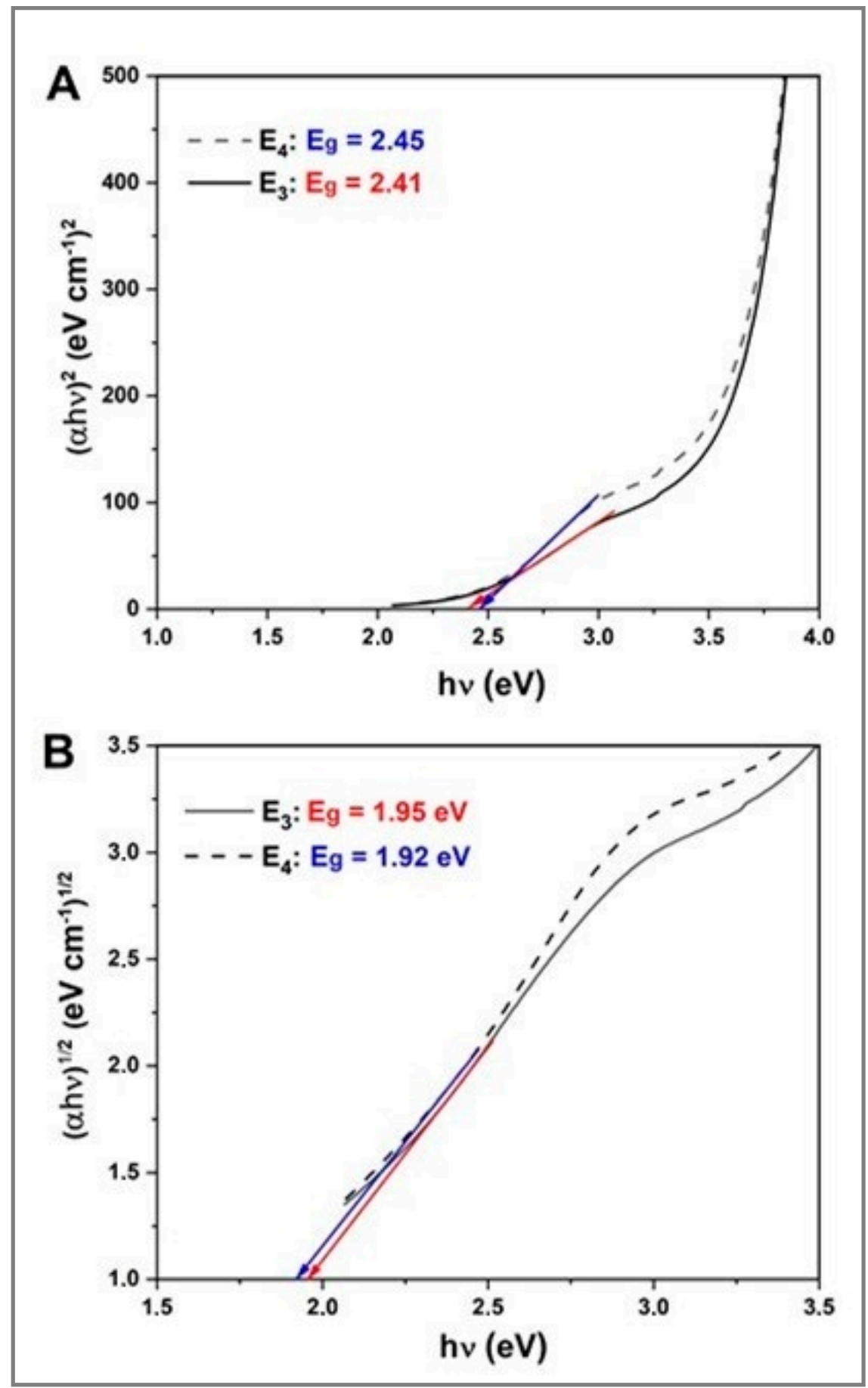

Figure 4. Tauc plot of $(\alpha \mathrm{h} v)^{1 / 2}$ vs. (hv) of $\mathrm{Ag}_{2} \mathrm{Se}$ NPs obtained from the samples: (A) $\mathrm{E}_{3}(3.4 \mathrm{mM}$

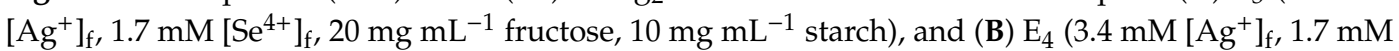
$\left[\mathrm{Se}^{4+}\right]_{\mathrm{f}}, 40 \mathrm{mg} \mathrm{mL}^{-1}$ fructose, $10 \mathrm{mg} \mathrm{mL}^{-1}$ starch).

\subsection{X-ray Diffraction}

$\mathrm{Ag}_{2} \mathrm{Se}$ NPs can exist as either an orthorhombic $\beta$-phase or a cubic $\alpha$-phase. According to Kumashiro et al. [55], $\mathrm{Ag}_{2} \mathrm{Se}$ is a non-stoichiometric compound in both phases that can co-exist with $\mathrm{Ag}_{2} \mathrm{Se}$ as a single phase. In addition, silver solubility is higher in the $\alpha$-phase than in the $\beta$-phase. Figure 5 displays the XRD pattern of $\mathrm{Ag}_{2} \mathrm{Se}$ NPs obtained from sample $\mathrm{E}_{3}$ made of $3.4 \mathrm{mM}\left[\mathrm{Ag}^{+}\right]_{\mathrm{f}}$ and $1.7 \mathrm{mM}\left[\mathrm{Se}^{4+}\right]_{\mathrm{f}}$ in the presence of $20 \mathrm{mg} \mathrm{mL}^{-1}$ fructose and $10 \mathrm{mg} \mathrm{mL}^{-1}$ starch. The following characteristic diffraction peaks are observed at $2 \theta=36.1^{\circ}(002), 44.1^{\circ}(112), 52.3^{\circ}(022)$ and $64.5^{\circ}(222)$, 
corresponding to planes of the cubic $\alpha-\mathrm{Ag}_{2}$ Se phase (JCPDS card no. 98-003-3627). The additional diffraction peaks observed at $2 \theta=25.8^{\circ}, 31.8^{\circ}, 33.3^{\circ}, 34.8^{\circ}, 39.5^{\circ}, 40.1^{\circ}, 43.5^{\circ}, 46.6^{\circ}, 50.9^{\circ}$ and $54.6^{\circ}$ correspond to the (012), (102), (112), (121), (031), (122), (210), (004), (221) and (222) planes, respectively, which can be assigned to the orthorhombic $\beta-\mathrm{Ag}_{2}$ Se phase (JCPDS card no. 98-001-5213) corresponding to the naumannite structure. Additionally, the prominent peak at $2 \theta=37.6^{\circ}$ suggests the presence of elemental silver and might correspond to the (111) plane of the face-centered cubic (fcc) structure of metallic silver (JCPDS file no. 03-0921). Furthermore, weak peaks can be attributed to selenium particles. These last two observations suggest that the precursor cations were reduced to their elemental forms in the final sample.

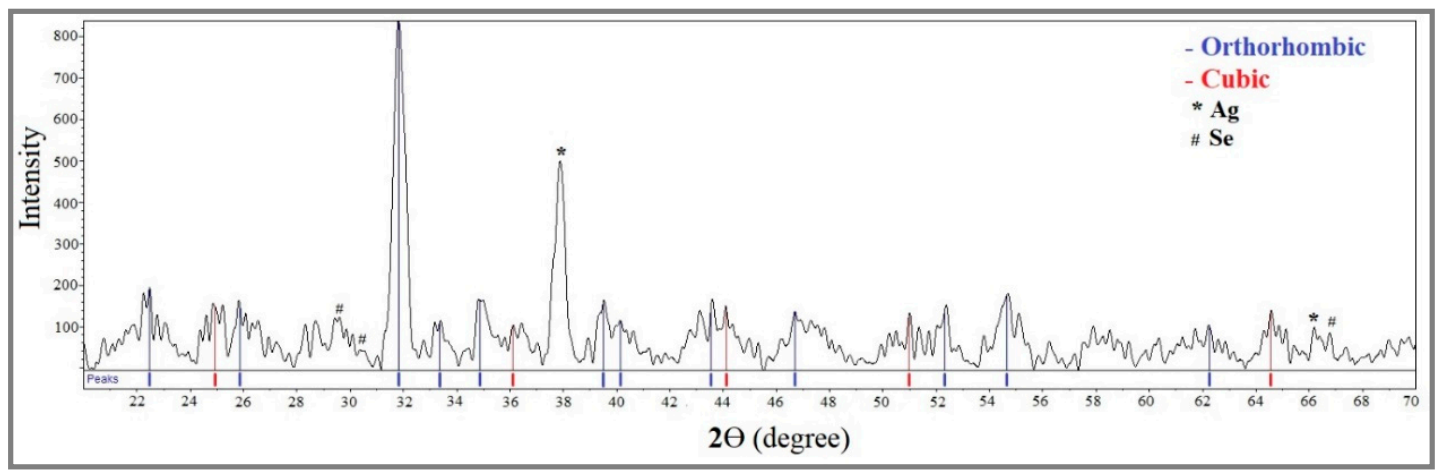

Figure 5. XRD diffractogram of $\mathrm{Ag}_{2} \mathrm{Se} \mathrm{NPs}$ from sample $\mathrm{E}_{3}$. The red and blue vertical lines correspond to the cubic and orthorhombic phases of $\mathrm{Ag}_{2} \mathrm{Se}$, respectively.

The presence of both orthorhombic and cubic phases of silver selenide is due to the acoustic cavitation phenomenon which causes the formation of vapor bubbles that, after collapsing, produce localized hot spots with temperatures up to $5000 \mathrm{~K}$, high pressures up to $20 \mathrm{MPa}$ and very high cooling rates [56]. In other words, this method offers optimal conditions for the simultaneous formation of both phases. Furthermore, widening appears in some of the diffraction peaks, mainly due to the small particle size as confirmed by TEM micrographs (vide infra) which yields peak overlapping of the two phases.

The average crystallite size of the as-produced $\mathrm{Ag}_{2} \mathrm{Se}$ NPs, determined from the half-width of the diffraction peak at $2 \theta=31.8^{\circ}$ corresponding to the (102) crystallographic plane of the $\beta$-phase using the Debye-Scherrer formula (Equation (2)), was found to be $26.5 \mathrm{~nm}$, in very good agreement with the size range of the nanoparticles $(5-40 \mathrm{~nm}$ ) deduced from the TEM micrographs (vide infra). This result is consistent with the size of the crystallite and similar phases previously reported in the literature $[52,54,56]$.

\subsection{Transmission Electron Microscopy}

TEM images revealed that the as-synthesized $\mathrm{Ag}_{2} \mathrm{Se}$ NPs from sample $\mathrm{E}_{3}\left(3.4 \mathrm{mM}\left[\mathrm{Ag}^{+}\right]_{\mathrm{f}}\right.$ $1.7 \mathrm{mM}\left[\mathrm{Se}^{4+}\right]_{\mathrm{f}}, 20 \mathrm{mg} \mathrm{mL}^{-1}$ fructose, $10 \mathrm{mg} \mathrm{mL}^{-1}$ starch) are round in shape, well-dispersed and well-defined with a broad size distribution ranging between 5 and $40 \mathrm{~nm}$ (Figure 6A,B). Figure 6C depicts the corresponding mean particle size distribution of the same sample. It shows the presence of a heterogeneous population of $\mathrm{Ag}_{2} \mathrm{Se}$ NPs with a bimodal size distribution. The average particle sizes estimated from TEM images with a population of 60 NPs were found to be 15 and $28 \mathrm{~nm}$, which could be due to a non-homogeneous reaction medium in terms of temperature, matter composition and processing time. In fact, the longer the ultrasonic radiation treatment, the higher the energy contribution. This triggers a greater cavitation effect that generates higher temperatures resulting in smaller mean NP diameters [57]. 


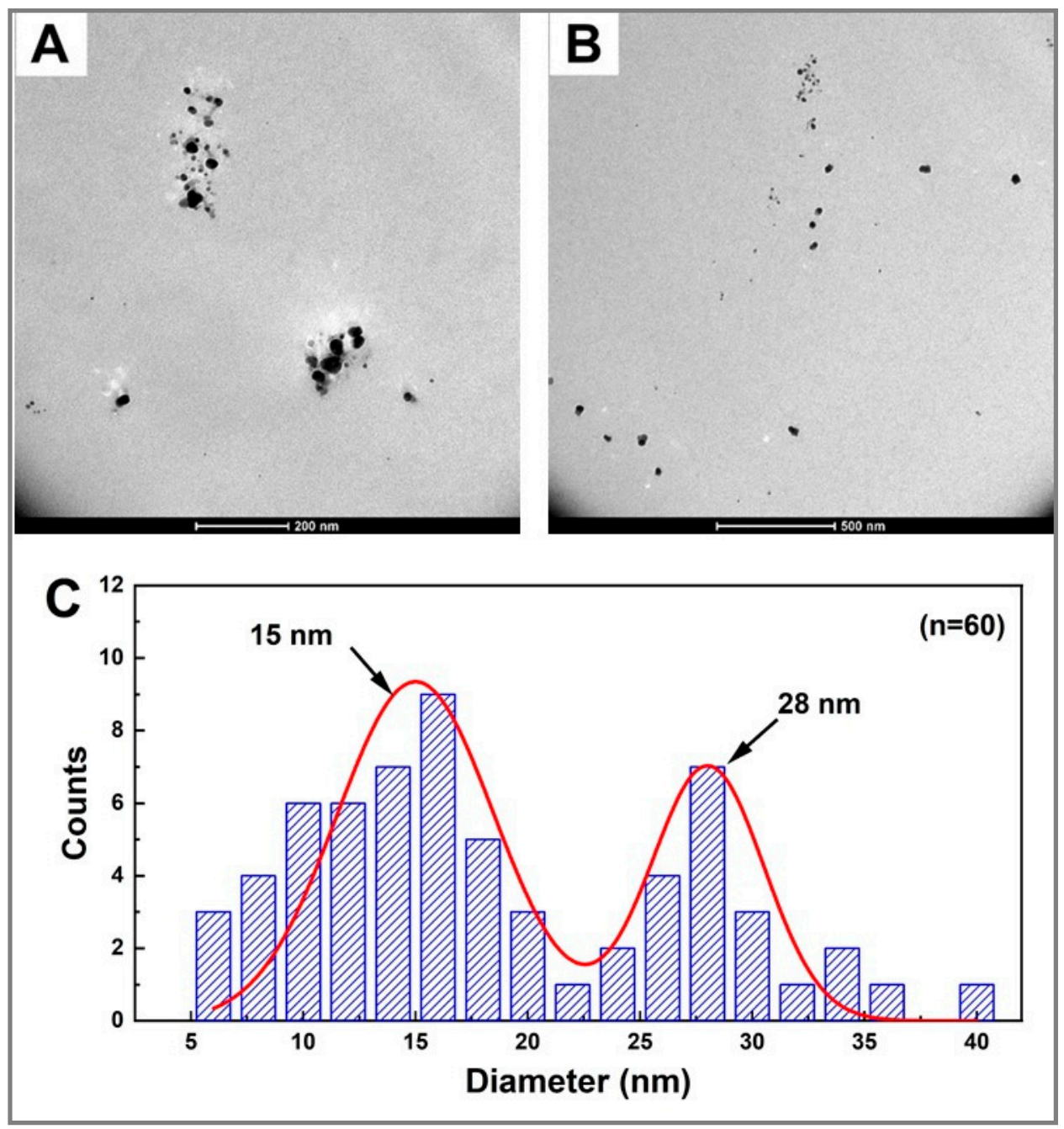

Figure 6. TEM micrographs of colloidal $\mathrm{Ag}_{2} \mathrm{Se}$ NPs from sample $\mathrm{E}_{3}$. (A,B) TEM images at different magnifications where the NPs are the black spots, and $(\mathbf{C})$ histogram plot with the average size values of $\mathrm{Ag}_{2} \mathrm{Se}$ NPs $(n=60)$.

Although no UV-Vis absorption band was recorded for the fructose-free control sample $\mathrm{C}_{2}(3.4 \mathrm{mM}$ $\left[\mathrm{Ag}^{+}\right]_{\mathrm{f}}, 1.7 \mathrm{mM}\left[\mathrm{Se}^{4+}\right]_{\mathrm{f}}, 10 \mathrm{mg} \mathrm{mL}^{-1}$ starch) (Figure 2B), the TEM micrograph of the same sample displays particles whose morphology varies from spherical to cubic and rod-shaped nanocrystals with a large particle size (Figure 7), as compared to Figure 6. Moreover, large aggregate nanostructures were formed; however, their chemical nature was not determined. This might be attributed to the fact that starch, a natural polysaccharide, can be decomposed into amylose and amylopectin, natural polymers formed by long chains of $\alpha$-D-glucose molecules. $\alpha$-D-glucose, like D-fructose, is a natural sugar that acts as a reducing agent in the production of inorganic NPs [58]. Therefore, starch, after its possible degradation, might have partially acted as the reducing agent instead of the stabilizing agent in the presence of fructose. Consequently, aggregated cubic and rod NPs of different sizes were formed since there is little to no stabilizing matrix to control the NP features (size, shape, stability), corroborating the absence of any UV-Vis absorption band. These results confirm the key roles of fructose as a strong reducing sugar and starch as an efficient stabilizing matrix in the ultrasound-assisted production of nanoparticles with interesting optical properties and controlled morphological features. 


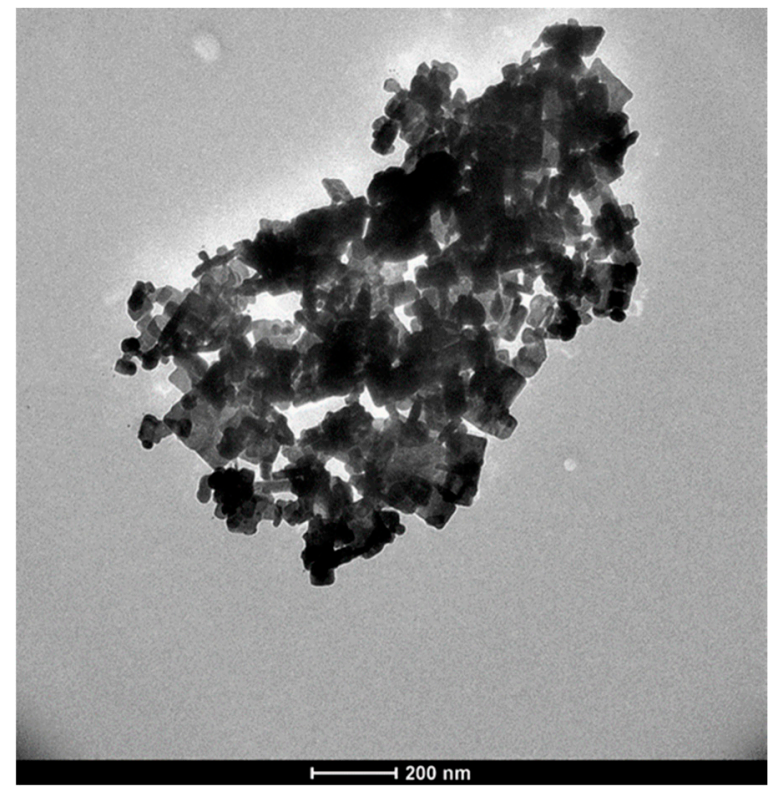

Figure 7. TEM image of $\mathrm{Ag}_{2} \mathrm{Se}$ NPs from sample $\mathrm{C}_{2}$ prepared in the absence of fructose.

\subsection{Scanning Electron Microscopy-Energy-Dispersive Spectroscopy}

SEM-EDS was used to study the chemical composition and purity of the as-obtained $\mathrm{Ag}_{2} \mathrm{Se}$ nanomaterial. The EDS spectrum, taken from selected areas of SEM images, exhibits prominent silver, selenium, carbon and oxygen peaks in the as-synthesized $\mathrm{Ag}_{2} \mathrm{Se}$ NPs (Figure 8). The detected $\mathrm{C}$ and $\mathrm{O}$ mainly arise from the stabilizing agent (starch) and the carbon grid used to mount the sample. The identification line for the major emission energy of selenium was observed in the range of 1.3-1.4 keV, while silver was observed in the range of $2.8-3.0 \mathrm{keV}$, corresponding in both cases to the $\mathrm{L}-\alpha$ peak of these elements. These selenium and silver peaks, due to their presence in $\mathrm{Ag}_{2} \mathrm{Se} \mathrm{NPs}$, are in good agreement with elemental peaks reported in the literature $[45,59]$. Therefore, the EDS spectrum confirms the presence of silver and selenium atoms in the as-synthesized $\mathrm{Ag}_{2} \mathrm{Se} \mathrm{NPs}$. Moreover, by dividing the peak intensity of $\mathrm{Ag}$ by the one of Se, this results in a 2:1 ratio, suggesting the chemical formula $\mathrm{Ag}_{2} \mathrm{Se}$.

\subsection{Biological Activity}

\subsubsection{Cytotoxicity Assessment by MTT Assay}

The cytotoxicity of the as-synthesized $\mathrm{Ag}_{2} \mathrm{Se}$ NPs was evaluated using the MTT assay considering that viability assays are key to explaining the cellular response to a toxic agent and provide information about the cell survival and metabolic activity. Human fibroblasts from the ATCC cell line were treated with different concentrations of $\mathrm{Ag}_{2} \mathrm{Se} \mathrm{NPs}$ for 24,48 and $72 \mathrm{~h}$. The obtained results indicated a range of cytotoxicity responses when compared to the control groups. 


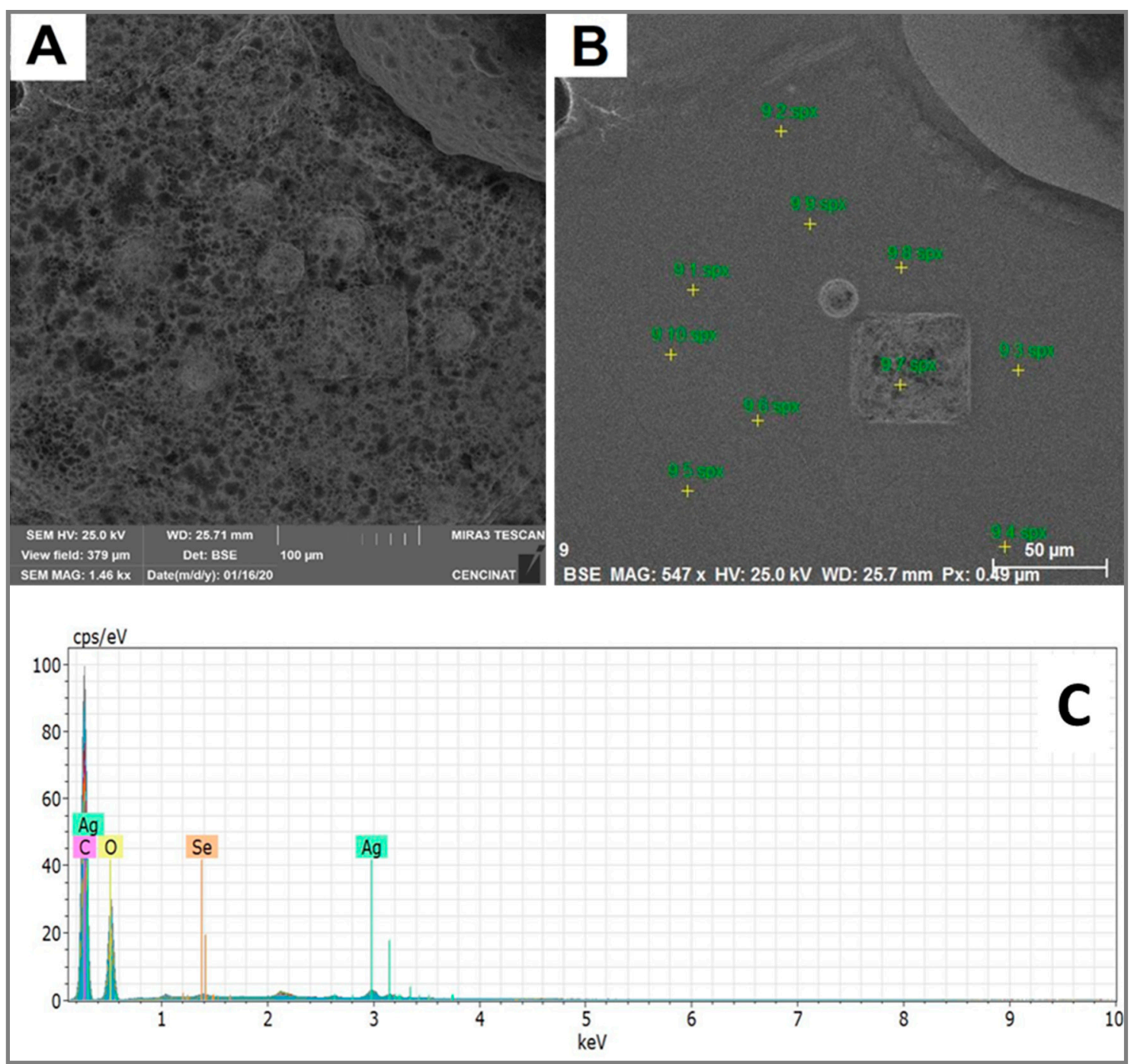

Figure 8. (A) SEM image; (B) selected areas for EDS spot analysis; and (C) EDS representative spectrum of $\mathrm{Ag}_{2} \mathrm{Se}$ NPs.

The as-synthesized $\mathrm{Ag}_{2} \mathrm{Se}$ NPs caused a significant reduction in the mitochondrial activity of ATCC cells with respect to the untreated control group (Figure 9). For instance, cultures at the studied $\mathrm{NP}$ concentrations of the $\mathrm{E}_{3}$ sample $\left(3.4 \mathrm{mM}\left[\mathrm{Ag}^{+}\right]_{\mathrm{f}}, 1.7 \mathrm{mM}\left[\mathrm{Se}^{4+}\right]_{\mathrm{f}}, 10 \mathrm{mg} \mathrm{mL}^{-1}\right.$ starch, $20 \mathrm{mg} \mathrm{mL}^{-1}$ fructose) showed a decrease in the cytotoxic effect with respect to the controls, reaching values close to $\sim 30 \%$ of viability after incubation for 24 and $48 \mathrm{~h}$, following a concentration-dependent effect (Figure 9C). After $72 \mathrm{~h}$ post-NP exposure, the cytotoxicity slightly increased as the viability decreased to $\sim 20 \%$, regardless of the lyophilized $\mathrm{Ag}_{2} \mathrm{Se} \mathrm{NP}$ concentration. On the other hand, samples $\mathrm{E}_{1}$ and $\mathrm{E}_{2}$ exhibited a higher cytotoxicity $\left(\sim 10 \%\right.$ cell viability) that was independent of the $\mathrm{Ag}_{2} \mathrm{Se} \mathrm{NP}$ concentration and exposure time (Figure 9A,B). According to these results, the as-synthesized $\mathrm{Ag}_{2} \mathrm{Se}$ NPs display a very strong biocidal activity against ATCC human fibroblast cell cultures. Moreover, the initial amount of fructose may impact this activity. 


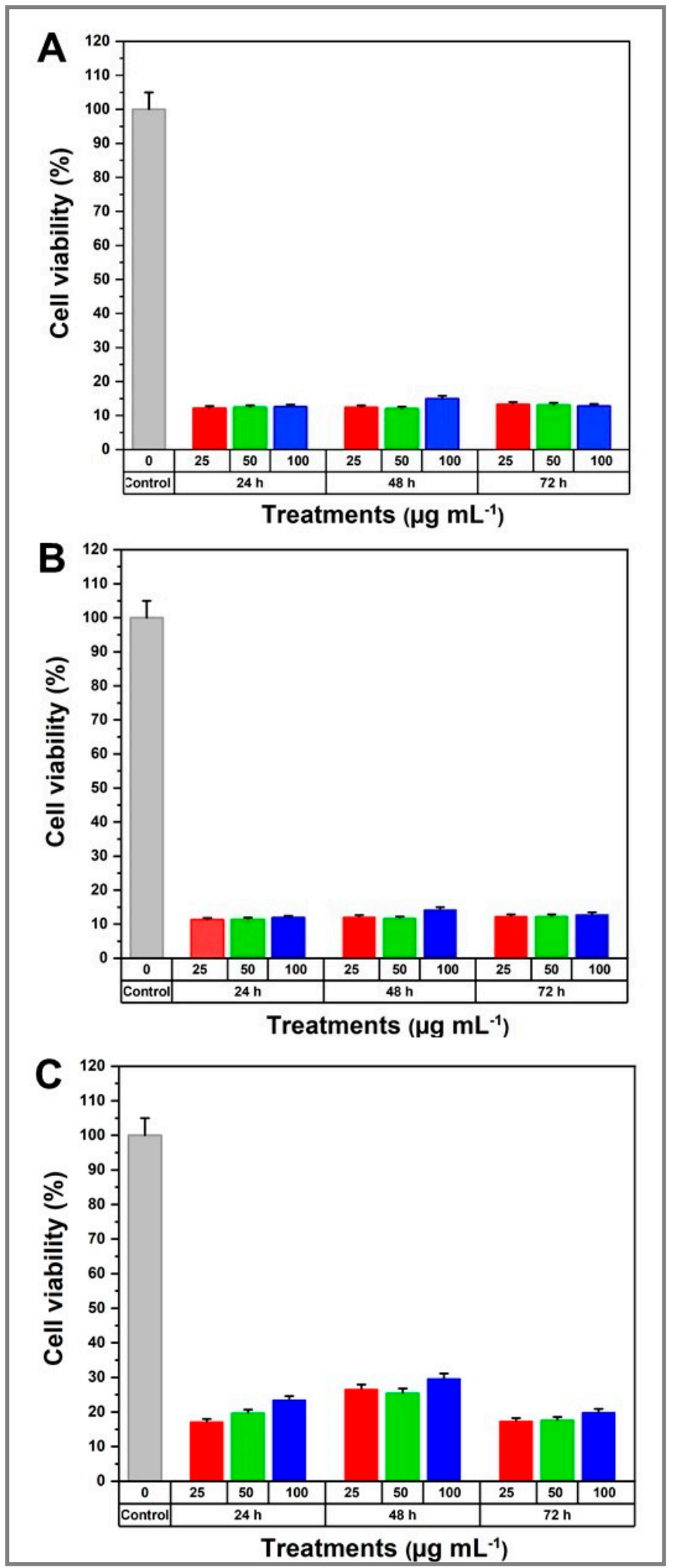

Figure 9. Cell viability of ATCC human fibroblasts exposed to $\mathrm{Ag}_{2}$ Se NPs at $0,25,50$ and $100 \mu \mathrm{g} \mathrm{mL}$ concentrations for 24,48 and $72 \mathrm{~h}$. (A) Sample $\mathrm{E}_{1}$; (B) sample $\mathrm{E}_{2}$; and (C) sample $\mathrm{E}_{3}$. 


\subsubsection{Bactericidal Tests}

The antibacterial activity of $\mathrm{Ag}_{2} \mathrm{Se} \mathrm{NPs}$ was investigated against the following pathogenic microorganisms by the disc diffusion method: Escherichia coli, Staphylococcus aureus, Salmonella typhimurium and Pseudomonas aeruginosa. The maximum zone of inhibition (MZI), summarized in Table 1, does not exhibit any trend related to the bacterial cell wall type. On the other hand, there seems to be a trend among the Gram-species. Indeed, the $\mathrm{Ag}_{2} \mathrm{Se} \mathrm{NPs}$ are very toxic towards E. coli, moderately toxic towards S. typhimurium and have the lowest toxicity to P. aeruginosa. Moreover, $\mathrm{Ag}_{2} \mathrm{Se} \mathrm{NPs}$ exhibit a very high toxicity against the Gram $+S$. aureus. Additionally, the initial amount of fructose, the only difference in the composition of $\mathrm{E}_{1}, \mathrm{E}_{2}$ and $\mathrm{E}_{3}$ samples, does not seem to impact the bactericidal activity of the as-obtained $\mathrm{Ag}_{2} \mathrm{Se}$ NPs. Furthermore, the increase in lyophilized $\mathrm{Ag}_{2} \mathrm{Se} \mathrm{NP}$ concentration expands the MZI for all the pathogenic bacteria (results not shown).

Table 1. Maximum zone of inhibition induced by $\mathrm{Ag}_{2} \mathrm{Se}$ NP samples calculated (in $\mathrm{mm}$ ) for Gram and Gram + bacteria.

\begin{tabular}{ccccc}
\hline \multirow{2}{*}{ Strain } & \multicolumn{4}{c}{ Maximum Zone of Inhibition (mm) } \\
\cline { 2 - 5 } & $\mathbf{E}_{\mathbf{1}}$ & $\mathbf{E}_{\mathbf{2}}$ & $\mathbf{E}_{\mathbf{3}}$ & Ref. Drug \\
\hline E. coli $(\mathrm{Gram}-)$ & 3.2 & 4.4 & 3.4 & 5.0 \\
S. typhimurium $(\mathrm{Gram}-)$ & 2.0 & 1.0 & 3.0 & 6.0 \\
P. aeruginosa $(\mathrm{Gram}-)$ & 0.5 & 0.0 & 1.0 & 3.0 \\
S. aureus $($ Gram +$)$ & 2.0 & 4.0 & 5.1 & 8.0 \\
\hline
\end{tabular}

The mechanism of the $\mathrm{Ag}_{2} \mathrm{Se} \mathrm{NP}$ bactericidal mode of action might differ according to the bacterial species and the composition of the samples. Gram - and Gram + bacteria show a similar antibiotic effect but at different sample compositions, as seen in the case of $P$. aeruginosa. In fact, only two $\mathrm{Ag}_{2} \mathrm{Se}$ NP samples, $E_{1}$ and $E_{3}$, at their maximum concentration showed a slight bactericidal effect, whereas all samples promoted a strong antibiotic effect at all NP concentrations against $E$. coli.

Although the antimicrobial mechanism of semiconductor NPs is not entirely understood, studies suggest this might be related to the formation of oxidative stress in cells, causing damage to their biomolecules that yields cell death [2]. In the present study, it is possible that $\mathrm{Ag}_{2} \mathrm{Se}$ NPs penetrate the cell membrane and irreversibly damage its antioxidative systems in a concentration-dependent manner.

\section{Materials and Methods}

\subsection{Materials}

For the preparation of the colloidal silver selenide NPs, selenous acid, $\mathrm{H}_{2} \mathrm{SeO}_{3}(99 \%$, Sigma-Aldrich, St. Louis, MO, USA), and silver nitrate, $\mathrm{AgNO}_{3}$ (99\%, Emsure, Darmstadt, Germany), were the precursors, $\mathrm{D}(+)$ fructose (Sigma-Aldrich, St. Louis, MO, USA) was the reducing agent, soluble corn starch (Sigma-Aldrich, St. Louis, MO, USA) was the stabilizing agent and deionized water (DIW) was the solvent. All chemicals were used without any additional chemical purification.

\subsection{Green Synthesis of Silver Selenide NPs}

The green synthesis of $\mathrm{Ag}_{2} \mathrm{Se}$ NPs was carried out via a facile co-precipitation method. Selenous acid $(0.44 \mathrm{~g})$ and $\mathrm{AgNO}_{3}(1.73 \mathrm{~g})$ were separately dissolved in DIW at room temperature (RT). The preparation of $\mathrm{Ag}_{2} \mathrm{Se}$ NPs and the associated control experiments are described in Table 2. For $\mathrm{Ag}_{2} \mathrm{Se} \mathrm{NP}$ preparation, $5 \mathrm{~mL}$ of $34 \mathrm{mM} \mathrm{H}_{2} \mathrm{SeO}_{3}$ and $10 \mathrm{~mL}$ of $34 \mathrm{mM} \mathrm{AgNO}_{3}$ were added into a $300 \mathrm{~mL}$ glass beaker. Immediately after, varying masses of starch and fructose were added to the reaction mixture and the total volume was brought to $100 \mathrm{~mL}$ by adding DIW. Finally, ultrasound irradiation was carried out using a Cole-Parmer ultrasonic processor (DAIGGER GE 505, $500 \mathrm{~W}, 20 \mathrm{kHz}$, Daigger Scientific, Buffalo Grove, IL, USA) whose probe was directly immersed into the reaction 
medium. The operating condition was 59-s pulse ON and 5-s pulse OFF with an amplitude of $70 \%$ for $30 \mathrm{~min}$. The formation of $\mathrm{Ag}_{2} \mathrm{Se}$ NPs was confirmed by a color change in the reaction mixture.

Table 2. Reaction parameters to produce $\mathrm{Ag}_{2} \mathrm{Se}$ NPs in a $100 \mathrm{~mL}$ reaction volume.

\begin{tabular}{|c|c|c|c|c|c|c|c|}
\hline \multirow{2}{*}{$\mathbf{N}^{\circ}$} & \multirow{2}{*}{ Composition } & V(DIW) & $\mathrm{S}$ & $\mathbf{F}$ & $\mathrm{V}\left(\mathrm{Ag}^{+}\right)$ & $\mathrm{V}\left(\mathrm{Se}^{4+}\right)$ & Time \\
\hline & & $\mathbf{m L}$ & $\mathrm{mg} \mathrm{mL^{-1 }}$ & $\mathbf{m g ~ m L ^ { - 1 }}$ & $\mathbf{m L}$ & mL & $\min$ \\
\hline$E_{1}$ & $\mathrm{AgNO}_{3}+\mathrm{H}_{2} \mathrm{SeO}_{3}+\mathrm{F}+\mathrm{S}$ & 85 & 10 & 5 & 10 & 5 & 30 \\
\hline $\mathrm{E}_{2}$ & $\mathrm{AgNO}_{3}+\mathrm{H}_{2} \mathrm{SeO}_{3}+\mathrm{F}+\mathrm{S}$ & 85 & 10 & 10 & 10 & 5 & 30 \\
\hline $\mathrm{E}_{3}$ & $\mathrm{AgNO}_{3}+\mathrm{H}_{2} \mathrm{SeO}_{3}+\mathrm{F}+\mathrm{S}$ & 85 & 10 & 20 & 10 & 5 & 30 \\
\hline $\mathrm{E}_{4}$ & $\mathrm{AgNO}_{3}+\mathrm{H}_{2} \mathrm{SeO}_{3}+\mathrm{F}+\mathrm{S}$ & 85 & 10 & 40 & 10 & 5 & 30 \\
\hline $\mathrm{C}_{1}$ & $\mathrm{AgNO}_{3}+\mathrm{H}_{2} \mathrm{SeO}_{3}$ & 85 & 0 & 0 & 10 & 5 & 30 \\
\hline $\mathrm{C}_{2}$ & $\mathrm{AgNO}_{3}+\mathrm{H}_{2} \mathrm{SeO}_{3}+\mathrm{S}$ & 85 & 10 & 0 & 10 & 5 & 30 \\
\hline $\mathrm{C}_{3}$ & $\mathrm{AgNO}_{3}+\mathrm{H}_{2} \mathrm{SeO}_{3}+\mathrm{F}$ & 85 & 0 & 40 & 10 & 5 & 30 \\
\hline
\end{tabular}

\subsection{Physico-Chemical Characterization}

\subsubsection{Ultraviolet-Visible (UV-Vis) Spectroscopy}

The absorption characteristics of the as-obtained $\mathrm{Ag}_{2} \mathrm{Se}$ NPs and their colloidal stability over time were determined by recording the UV-Vis spectra from 300 to $600 \mathrm{~nm}$ using a LAMBDA $1050 \mathrm{UV}-\mathrm{Vis}$ Spectrophotometer (Perkin Elmer, Inc., Shelton, CT, USA). All measurements were performed in a quartz cuvette, using DIW as the blank. Subsequently, all the samples were stored at RT in the dark.

Starting from the UV-Vis spectra of samples $E_{3}$ and $E_{4}$, samples with fructose concentrations of 20 and $40 \mathrm{mg} \mathrm{L}^{-1}$, respectively, the band gap of the as-produced $\mathrm{Ag}_{2} \mathrm{Se}$ NPs was determined using a Tauc plot relating the absorption coefficient $(\alpha)$ and the photon energy $(h v)$, as depicted in Equation (1):

$$
\alpha h v=A\left(h v-E_{g}\right)^{1 / n}
$$

where $E_{g}$ is the band gap in $\mathrm{eV}, h$ is Planck's constant $\left(6.62610-34 \mathrm{~J} \mathrm{~s}^{-1}\right), v$ is the frequency in $\mathrm{Hz}, A$ and $\alpha$ are constants and " $n$ " is $1 / 2,3 / 2,2$ or 3 for direct allowed, direct forbidden, indirect allowed and indirect forbidden transitions, respectively. The extrapolation of the linear portion of the curve with the $x$-axis gives the value of the $E_{g}$.

\subsubsection{X-ray Diffraction (XRD)}

XRD (PANanalytical, EMPYREAN, Almelo, The Netherlands) analysis on lyophilized $\mathrm{Ag}_{2} \mathrm{Se}$ NPs was carried out to identify the phase structure and determine the crystallite size using a $\theta-2 \theta$ configuration (generator-detector), with the $\mathrm{Cu}-\mathrm{K} \alpha$ excitation source at $\lambda=1.54059 \AA$.

Additionally, the broadening of the diffraction peak in the XRD is related to the particle size by the Debye-Scherrer formula (Equation (2)) to obtain the average crystallite size:

$$
\mathrm{L}=\mathrm{K} \lambda / \mathrm{B} \cos \theta
$$

where $\lambda$ is the $X$-ray wavelength $(0.154059 \mathrm{~nm}), B$ is the line broadening at full width half maximum (FWHM), $\theta$ is the diffraction angle, $\mathrm{K}$ is the constant related to crystalline shape ( 0.93 for spherical NPs) and $\mathrm{L}$ is the linear dimension of the particle.

\subsubsection{Transmission Electron Microscopy (TEM)}

TEM (FEI, TECNAI, G2spirit twin, Holland) was employed to determine the size, shape and morphologies of the as-produced $\mathrm{Ag}_{2} \mathrm{Se}$ NPs. The samples were prepared by casting one drop of $\mathrm{Ag}_{2} \mathrm{Se}$ NP solution onto a carbon-coated copper grid and dried in ambient air at RT.

TEM micrographs at 200 and $500 \mathrm{~nm}$ scales were subjected to particle size distribution analyses using ImageJ software (developed by the National Institutes of Health (NIH), Bethesda, MD, USA) to 
generate. CSV files with information about the cross-sectional area of the as-synthesized nanoparticles. As $\mathrm{Ag}_{2} \mathrm{Se}$ NPs are spherical, the diameter was calculated from the area $\left(\mathrm{A}=\pi \mathrm{D}^{2} / 4\right)$. Then, using OriginPro software, the size distribution histogram of $2 \mathrm{~nm}$ resolution was generated and fitted with a Gaussian function to determine the average size of the NPs.

\subsubsection{Scanning Electron Microscopy-Energy-Dispersive Spectroscopy (SEM-EDS)}

The elemental analysis and mapping of $\mathrm{Ag}_{2} \mathrm{Se}$ NPs were performed non-destructively using SEM (TESCAN, MIRA 3, Brno, Czech Republic) equipped with EDS (Bruker Nano GmbH, Quantax, Berlin, Germany). The samples were prepared by casting one drop of the $\mathrm{Ag}_{2} \mathrm{Se}$ NP reaction media onto a stub previously covered with two layers of double-coated carbon conductive tape and dried in ambient air at RT.

\subsection{Biological Activity of $\mathrm{Ag}_{2} \mathrm{Se}$ NPs}

\subsubsection{MTT Assay Using Human Fibroblasts}

The ATCC human fibroblast (HFF) cell line was grown in DMEM medium supplemented with $10 \% \mathrm{wt} / \mathrm{v}$ fetal bovine serum (FBS) and $1 \% \mathrm{wt} / \mathrm{v}$ penicillin/streptomycin. Cells were incubated at $37^{\circ} \mathrm{C}$ in a humidified $5 \% \mathrm{CO}_{2}$ atmosphere. Subsequently, the cells were harvested using $0.25 \% \mathrm{wt} / \mathrm{v}$ trypsin-EDTA (1X) and the cell count was performed using trypan blue and Neubauer chamber. An amount of $100 \mu \mathrm{L}$ of the cell suspension was dispersed to achieve $10^{4}$ cells/well in 96-well culture plates and incubated under the same conditions for another $24 \mathrm{~h}$. Then, the medium was replaced with a medium containing the lyophilized $\mathrm{Ag}_{2} \mathrm{Se}$ NPs at different concentrations: 0 (control), 25, 50 and $100 \mu \mathrm{g} \mathrm{mL}{ }^{-1}$. After 24, 48 and $72 \mathrm{~h}$ incubation, the MTT solution at $0.5 \mathrm{mg} \mathrm{mL}^{-1}$ was added to each well and incubated for another $4 \mathrm{~h}$ at $37^{\circ} \mathrm{C}$. Then, formazan crystals were solubilized with $100 \mu \mathrm{L}$ of $10 \%$ SDS per well. The absorbance of each well was measured at $570 \mathrm{~nm}$ with a Multiskan microplate reader (USA). Each assay, made in duplicate, included a control-containing culture medium. The cell viability percentage was obtained using Equation (3):

$$
\text { Cell viability } \%=(\text { Absorbance of treated cells/Absorbance of untreated cells }) * 100
$$

\subsubsection{Antibacterial Activity}

The antibacterial activity of $\mathrm{Ag}_{2} \mathrm{Se}$ NPs against several species of bacteria was investigated using a disc diffusion assay. First, $100 \mu \mathrm{L}$ of bacteria were plated on an LB plate to obtain a bacterial lawn. Then, filter paper discs were dipped into colloidal $\mathrm{Ag}_{2} \mathrm{Se}$ NPs at different concentrations of lyophilized $\mathrm{Ag}_{2}$ Se NPs: 0 (control), 25, 50 and $100 \mu \mathrm{g} \mathrm{mL}^{-1}$, before being placed on the Petri dishes that contained the bacterial lawns and incubated overnight at $37^{\circ} \mathrm{C}$. The pathogenic bacteria Escherichia coli, Staphylococcus aureus, Salmonella typhimurium and Pseudomonas aeruginosa were used as model strains. On the other hand, $1 \% \mathrm{wt} / \mathrm{v}$ penicillin/streptomycin solution was used as a reference drug. Finally, the maximum zone of inhibition, expressed as diameter in $\mathrm{mm}$, was measured.

\section{Conclusions}

The ultrasound-assisted aqueous green synthesis of silver selenide nanoparticles was successful and demonstrated the ability of fructose and starch as biological reducing and stabilizing agents, respectively. The formation of $\mathrm{Ag}_{2} \mathrm{Se} \mathrm{NPs}$ was confirmed by a visual color change in the samples after ultrasound irradiation in the presence of both green agents, as well as the UV-Vis spectra with an absorption band in the range of $385-446 \mathrm{~nm}$. The absorbance intensity was observed to be a function of fructose concentration. In addition to obtaining very stable samples, the band gap of these $\mathrm{Ag}_{2} \mathrm{Se}$ NPs is impacted by their size and crystallographic phase. Nonetheless, the fructose amount does not seem to influence their band gap. The XRD patterns showed the presence of both orthorhombic and cubic phases of silver selenide, as well as some prominent peaks that suggest the presence of 
both elemental silver and selenium. The crystallite size was comparable to the NP size that was determined from TEM micrographs displaying NPs ranging from 5 to $40 \mathrm{~nm}$. Moreover, TEM images confirmed the production of uniform, well-dispersed and spherical $\mathrm{Ag}_{2}$ Se NPs only in the presence of both natural agents, fructose and starch. The SEM-EDS elemental analysis corroborated the previous results. In addition to $C$ and $O$ peaks due mainly to starch that acted as the capping agent, the EDS spectrum showed the two prominent elemental L- $\alpha$ peaks related to silver and selenium in a 2:1 ratio, confirming $\mathrm{Ag}_{2} \mathrm{Se} \mathrm{NP}$ formation. Green-synthesized silver selenide nanoparticles exhibited a high cytotoxic response to the ATCC human fibroblast cell line and a concentration-dependent bactericidal activity against $E$. coli, S. aureus, P. aeruginosa and P. typhimurium. Overall, our findings' novelty resides in the efficacy of widespread, renewable and cheap biomolecules to promote the ultrasound-assisted aqueous synthesis of functional $\mathrm{Ag}_{2}$ Se NPs via a one-step, easy and time-efficient methodology whose versatility may benefit the fabrication of a wide range of nanomaterials of unique features and promising bio-applications.

Author Contributions: Conceptualization, D.A.G., L.M. and S.A.D.; methodology, D.A.G., L.M., K.V. and A.G.; software, D.A.G., E.Á., T.T. and S.A.D.; validation, C.J. and S.A.D.; formal analysis, D.A.G., T.T., E.Á. and S.A.D.; investigation, D.A.G., C.J. and S.A.D.; resources, A.D., M.T.A., E.Á. and T.T.; data curation, D.A.G., E.Á., T.T., M.T.A., C.J. and S.A.D.; writing—original draft preparation, D.A.G.; writing—review and editing, E.Á., A.D., T.T., M.T.A., C.J. and S.A.D.; visualization, D.A.G., L.M., E.Á., C.J. and S.A.D.; supervision, C.J. and S.A.D.; project administration, S.A.D. All authors have read and agreed to the published version of the manuscript.

Funding: This research received no external funding.

Conflicts of Interest: The authors declare no conflict of interest.

\section{References}

1. Murray, C.B.; Kagan, C.R. Synthesis and characterization of monodisperse nanocrystals and close-packed nanocrystals assemblies. Annu. Rev. Mater. Sci. 2000, 30, 545-610. [CrossRef]

2. Delgado-Beleño, Y.; Martinez-Nuñez, C.E.; Cortez-Valadez, M.; Flores-López, N.S.; Flores-Acosta, M. Optical properties of silver, silver sulfide and silver selenide nanoparticles and antibacterial applications. Mater. Res. Bull. 2018, 99, 385-392. [CrossRef]

3. Zrazhevskiy, P.; Sena, M.; Gao, X. Designing multifunctional quantum dots for bioimaging, detection, and drug delivery. Chem. Soc. Rev. 2010, 39, 4326-4354. [CrossRef] [PubMed]

4. Sperling, R.A.; Parak, W.J. Surface modification, functionalization and bioconjugation of colloidal Inorganic nanoparticles. Philos. Trans. R. Soc. A Math. Phys. Eng. Sci. 2010, 368, 1333-1383. [CrossRef] [PubMed]

5. Talapin, D.V.; Lee, J.S.; Kovalenko, M.V.; Shevchenko, E.V. Prospects of colloidal nanocrystals for electronic and optoelectronic applications. Chem. Rev. 2010, 110, 389-458. [CrossRef] [PubMed]

6. Colvin, V.L.; Schlamp, M.C.; Alivisatos, A.P. Light-emitting diodes made from cadmium selenide nanocrystals and a semiconducting polymer. Nature 1994, 370, 354-357. [CrossRef]

7. Helan, P.P.J.; Mohanraj, K.; Sivakumar, G. Synthesis and characterization of $\beta-\mathrm{Ag}_{2} \mathrm{Se}$ and $\beta$-AgCuSe nanoparticles via facile precipitation route. Trans. Nonferrous Met. Soc. China 2015, 25, 2241-2246.

8. Tang, H.; Yang, S.T.; Yang, Y.F.; Ke, D.M.; Liu, J.H.; Chen, X.; Wang, H.; Liu, Y. Blood clearance, distribution, transformation, excretion, and toxicity of near-infrared quantum dots $\mathrm{Ag}_{2} \mathrm{Se}$ in mice. ACS Appl. Mater. Interfaces 2016, 8, 17859-17869. [CrossRef]

9. Wu, T.; Liang, X.; He, K.; Wei, T.; Wang, Y.; Zou, L.; Bai, C.; Liu, N.; Zhang, T.; Xue, Y.; et al. The role of NLRP3 inflammasome activation in the neuroinflammatory responses to $\mathrm{Ag}_{2}$ Se quantum dots in microglia. Nanoscale 2019, 11, 20820-20836. [CrossRef]

10. Shimojo, F.; Okazaki, H. Boundary condition effect in MD simulation: A case of the $\alpha \rightarrow \beta$ phase transition in superionic conductor $\mathrm{Ag}_{2}$ Se. J. Phys. Soc. Jpn. 1993, 62, 179-182. [CrossRef]

11. Ferhat, M.; Nagao, J. Thermoelectric and transport properties of $\beta-\mathrm{Ag}_{2}$ Se compounds. J. Appl. Phys. 2000, 88, 813-816. [CrossRef]

12. Cao, H.; Xiao, Y.; Lu, Y.; Yin, J.; Li, B.; Wu, S.; Wu, X. $\mathrm{Ag}_{2}$ Se complex nanostructures with photocatalytic activity and superhydrophobicity. Nano Res. 2010, 3, 863-873. [CrossRef] 
13. Yang, F.; Xiong, S.; Xia, Z.; Liu, F.; Han, C.; Zhang, D. Two-step synthesis of silver selenide semiconductor with a linear magnetoresistance effect. Semicond Sci. Technol. 2012, 27, 125017. [CrossRef]

14. Schoen, D.T.; Xie, C.; Cui, Y. Electrical switching and phase transformation in silver selenide nanowires. J. Am. Chem. Soc. 2007, 129, 4116-4117. [CrossRef]

15. Liu, H.; Zhang, B.; Shi, H.; Tang, Y.; Jiao, K.; Fu, X. Hydrothermal synthesis of monodisperse $\mathrm{Ag}_{2} \mathrm{Se}$ nanoparticles in the presence of PVP and KI and their application as oligonucleotide labels. J. Mater. Chem. 2008, 18, 2573-2580. [CrossRef]

16. Sahu, A.; Qi, L.; Kang, M.S.; Deng, D.; Norris, D.J. Facile synthesis of silver chalcogenide ( $\operatorname{Ag}_{2} E . ; E=S e, S$, Te) semiconductor nanocrystals. J. Am. Chem. Soc. 2011, 133, 6509-6512. [CrossRef] [PubMed]

17. Pandiaraman, M.; Soundararajan, N. Micro-Raman studies on thermally evaporated $\mathrm{Ag}_{2} \mathrm{Se}$ thin films. J. Theor. Appl. Phys. 2012, 6, 7. [CrossRef]

18. Kharissova, O.V.; Dias, H.V.R.; Kharisov, B.I.; Pérez, B.O.; Pérez, V.M.J. The greener synthesis of nanoparticles. Trends Biotechnol. 2013, 31, 240-248. [CrossRef]

19. Dahoumane, S.A.; Jeffryes, C.; Mechouet, M.; Agathos, S.N. Biosynthesis of inorganic nanoparticles: A fresh look at the control of shape, size and composition. Bioengineering 2017, 4, 14. [CrossRef]

20. Rahman, A.; Lin, J.; Jaramillo, F.E.; Bazylinski, D.A.; Je, C.; Dahoumane, S.A. In vivo biosynthesis of inorganic nanomaterials using eukaryotes-A review. Molecules 2020, 25, 3246. [CrossRef]

21. Dahoumane, S.A.; Mechouet, M.; Wijesekera, K.; Filipe, C.D.; Sicard, C.; Bazylinski, D.A.; Jeffryes, C. Algae-mediated biosynthesis of inorganic nanomaterials as a promising route in nanobiotechnology-A review. Green Chem. 2017, 19, 552-587. [CrossRef]

22. Shan, W.J.; Yan, Q.; Li, D.; Fang, D.W.; Zang, S.L. Ultrasonic synthesis of $\mathrm{Ag}_{2}$ Se nanocrystal in perrhenate solution. Adv. Mater. Res. 2014, 919, 2109-2111. [CrossRef]

23. Zhan, J.H.; Yang, X.G.; Li, S.D.; Wang, D.W.; Xie, Y.; Qian, Y.T. Synthesis of $\mathrm{Ag}_{2}$ Se by sonochemical reaction of Se with $\mathrm{AgNO}_{3}$ in non-aqueous solvent. Int. J. Inorg. Mater. 2001, 3, 47-49. [CrossRef]

24. Li, B.; Xie, Y.; Huang, J.; Qian, Y. Sonochemical synthesis of silver, copper and lead selenides. Ultrason. Sonochem. 1999, 6, 217-220. [CrossRef]

25. Henam, S.D.; Ahmad, F.; Shah, M.A.; Parveen, S.; Wani, A.H. Microwave synthesis of nanoparticles and their antifungal activities. Spectrochim. Acta Part A Mol. Biomol. Spectrosc. 2019, 213, 337-341. [CrossRef] [PubMed]

26. Kumar, S.V.; Bafana, A.P.; Pawar, P.; Rahman, A.; Dahoumane, S.A.; Jeffryes, C.S. High conversion synthesis of $<10 \mathrm{~nm}$ starch-stabilized silver nanoparticles using microwave technology. Sci. Rep. 2018, 8, 5106.

27. Kumar, S.V.; Bafana, A.P.; Pawar, P.; Faltane, M.; Rahman, A.; Dahoumane, S.A.; Kucknoor, A.; Jeffryes, C.S. Optimized production of antibacterial copper oxide nanoparticles in a microwave-assisted synthesis reaction using response surface methodology. Colloids Surfaces A Physicochem. Eng. Asp. 2019, 573, 170-178. [CrossRef]

28. Kumar, A.; Kuang, Y.; Liang, Z.; Sun, X. Microwave chemistry, recent advancements, and eco friendly microwave-assisted synthesis of nanoarchitectures and their applications: A review. Mater. Today Nano 2020, 11, 100076. [CrossRef]

29. Luo, Y.; Shen, S.; Luo, J.; Wang, X.; Sun, R. Green synthesis of silver nanoparticles in xylan solution via Tollens reaction and their detection for $\mathrm{Hg}^{2+}$. Nanoscale 2015, 7, 690-700. [CrossRef]

30. Durmazel, S.; Üzer, A.; Erbil, B.; Sayln, B.; Apak, R. Silver nanoparticle formation-based colorimetric determination of reducing sugars in food extracts via Tollens' reagent. ACS Omega 2019, 4, 7596-7604. [CrossRef]

31. Nel, A.E.; Mädler, L.; Velegol, D.; Xia, T.; Hoek, E.M.; Somasundaran, P.; Klaessig, F.; Castranova, V.; Thompson, M. Understanding biophysicochemical interactions at the nano-biointerface. Nat. Mater. 2009, 8, 543-557. [CrossRef]

32. Raveendran, P.; Fu, J.; Wallen, S.L. Completely “Green" Synthesis and stabilization of metal nanoparticles. J. Am. Chem Soc. 2003, 125, 13940-13941. [CrossRef]

33. Dubertret, B.; Skourides, P.; Norris, D.J.; Noireaux, V.; Brivanlou, A.H.; Libchaber, A. In vivo imaging of quantum dots encapsulated in phospholipid micelles. Science 2002, 298, 1759-1762. [CrossRef]

34. Roy, A.; Bulut, O.; Some, S.; Mandal, A.K.; Yilmaz, M.D. Green synthesis of silver nanoparticles: Biomoleculenanoparticle organizations targeting antimicrobial activity. RSC Adv. 2019, 9, 2673-2702. [CrossRef]

35. Sharma, G.; Sharma, A.R.; Bhavesh, R.; Park, J.; Ganbold, B.; Nam, J.S.; Lee, S.S. Biomolecule-mediated synthesis of selenium nanoparticles using dried Vitis vinifera (raisin) extract. Molecules 2014, 19, 2761-2770. [CrossRef] 
36. Ocsoy, I.; Tasdemir, D.; Mazicioglu, S.; Celik, C.; Katı, A.; Ulgen, F. Biomolecules incorporated metallic nanoparticles synthesis and their biomedical applications. Mater. Lett. 2018, 2012, 45-50. [CrossRef]

37. Castro-Guerrero, C.F.; Morales-Cepeda, A.B.; Hernández-Vega, L.K.; Díaz-Guillén, M.R. Fructose-mediated gold nanoparticles synthesis. Cogent Chem. 2018, 4, 1447262. [CrossRef]

38. Mohanpuria, P.; Rana, N.K.; Yadav, S.K. Biosynthesis of nanoparticles: Technological concepts and future applications. J. Nanopart. Res. 2008, 10, 507-517. [CrossRef]

39. Singh, P.; Garg, A.; Pandit, S.; Mokkapati, V.R.S.S.; Mijakovic, I. Antimicrobial effects of biogenic nanoparticles. Nanomaterials 2018, 8, 1009. [CrossRef]

40. Marulasiddeshwara, M.B.; Dakshayani, S.S.; Sharath Kumar, M.N.; Chethana, R.; Raghavendra Kumar, P.; Devaraja, S. Facile one-pot green synthesis, antibacterial, antifungal, antioxidant and antiplatelet activities of lignin capped silver nanoparticles: A promising therapeutic agent. Mater. Sci. Eng. C 2017, 81, 182-190. [CrossRef]

41. Allahverdiyev, A.M.; Kon, K.V.; Abamor, E.S.; Bagirova, M.; Rafailovich, M. Coping with antibiotic-resistant: Combining nanoparticles with antibiotics and other antimicrobial agents. Expert Rev. 2011, 9, 1035-1052.

42. Gao, W.; Thamphiwatana, S.; Angsantikul, P.; Zhang, L. Nanoparticle approaches against bacterial infections. Wiley Interdiscip. Rev. Nanomed. Nanobiotechnol. 2014, 6, 532-547. [CrossRef]

43. Van Giau, V.; An, S.S.A.; Hulme, J. Recent advances in the treatment of pathogenic infections using antibiotics and nano-drug delivery vehicles. Drug Des. Devel. Ther. 2019, 13, 327-343. [CrossRef]

44. Patel, G.; Huprikar, S.; Factor, S.H.; Jenkins, S.G.; Calfee, D.P. Outcomes of carbapenem-resistant Klebsiella pneumoniae infection and the impact of antimicrobial and adjunctive therapies. Infect. Control Hosp. Epidemiol. 2008, 29, 1099-1106. [CrossRef]

45. Sibiya, P.N.; Moloto, M.J. Effect of precursor concentration and $\mathrm{pH}$ on the shape and size of starch capped silver selenide $\left(\mathrm{Ag}_{2} \mathrm{Se}\right)$ nanoparticles. Chalcogenide Lett. 2014, 11, 577-588.

46. Sibiya, N.P.; Moloto, M.J. Shape control of silver selenide nanoparticles using green capping molecules. Green Process. Synth. 2017, 6, 183-188. [CrossRef]

47. Kumar, B.; Smita, K.; Cumbal, L.; Debut, A. Green synthesis of silver nanoparticles using Andean blackberry fruit extract. Saudi J. Biol. Sci. 2017, 24, 45-50. [CrossRef]

48. Zou, J.; Xu, Y.; Hou, B.; Wu, D.; Sun, Y. Controlled growth of silver nanoparticles in a hydrothermal process. China Particuol. 2007, 5, 206-212. [CrossRef]

49. Ahmed, S.; Ullah, S.; Ahmad, M.; Swami, B.L.; Ikram, S. Green synthesis of silver nanoparticles using Azadirachta indica aqueous leaf extract. J. Radiat. Res. Appl. Sci. 2016, 9, 1. [CrossRef]

50. Rahman, A.; Kumar, S.; Bafana, A.; Dahoumane, S.A.; Jeffryes, C. Biosynthetic conversion of $\mathrm{Ag}^{+}$to highly stable $\mathrm{Ag}^{0}$ nanoparticles by wild type and cell wall deficient strains of Chlamydomonas reinhardtii. Molecules 2019, 24, 98. [CrossRef]

51. Anthony, S.P. Synthesiss of $\mathrm{Ag}_{2} \mathrm{~S}$ and $\mathrm{Ag}_{2} \mathrm{Se}$ nanoparticles in self assembled block copolymer micelles and nano-arrays fabrication. Matter. Lett. 2009, 63, 3405-3409. [CrossRef]

52. Fernández-Díaz, E.; Espinoza-Martinez, A.B.; Flores-Pacheco, A.; Ramírez-Bon, R.; Castillo, S.J.; Ochoa Landin, R. Synthesis and characterization of silver selenide thin films by chemical bath deposition and ionic exchange. J. Electron. Mater. 2019, 48, 3405-3409.

53. Pejova, B.; Najdoski, M.; Grozdanov, I.; Dey, S.K. Chemical bath deposition of nanocrystalline (111) textured $\mathrm{Ag}_{2}$ Se thin films. Mater. Lett. 2000, 43, 269-273. [CrossRef]

54. Harpeness, R.; Palchik, O.; Gedanken, A.; Palchik, V.; Amiel, S.; Slifkin, M.A.; Weiss, A.M. Preparation and characterization of $\mathrm{Ag}_{2} \mathrm{E}(\mathrm{E}=\mathrm{Se}, \mathrm{Te})$ using the sonochemically assisted polyol method. Chem Mater. 2002, 14, 2094-2102. [CrossRef]

55. Kumashiro, Y.; Ohachi, T.; Taniguchi, I. Phase transition and cluster formation in silver selenide. Solid State Ion. 1996, 86-88, 761-766. [CrossRef]

56. Kristl, M.; Gyergyek, S.; Kristl, J. Synthesis and characterization of nanosized silver chalcogenides under ultrasonic irradiation. Mater. Express 2015, 5, 359-366. [CrossRef]

57. Tsai, M.L.; Bai, S.W.; Chen, R.H. Cavitation effects versus stretch effects resulted in different size and polydispersity of ionotropic gelation chitosan-sodium tripolyphosphate nanoparticle. Carbohydr. Polym. 2008, 71, 448-457. [CrossRef]

58. Kumar, B.; Smita, K.; Cumbal, L.; Debut, A.; Pathak, R.N. Sonochemical synthesis of silver nanoparticles using starch: A comparison. Bioinorg. Chem. Appl. 2014, 2014, 784268. [CrossRef] 
59. Yao, Q.; Arachchige, I.U.; Brock, S.L. Expanding the repertoire of chalcogenide nanocrystal networks: $\mathrm{Ag}_{2} \mathrm{Se}$ gels and aerogels by cation exchange reactions. J. Am. Chem. Soc. 2009, 131, 2800-2801. [CrossRef]

Sample Availability: Samples of the compounds are not available from the authors.

Publisher's Note: MDPI stays neutral with regard to jurisdictional claims in published maps and institutional affiliations.

(C) 2020 by the authors. Licensee MDPI, Basel, Switzerland. This article is an open access article distributed under the terms and conditions of the Creative Commons Attribution (CC BY) license (http://creativecommons.org/licenses/by/4.0/). 